\title{
The Effect of Omnichannel Strategy on Customer Loyalty through Customer Experience in KCA (Kredit Cepat Aman) Product at PT. Pegadaian (Persero) Labuhan Deli Sub-Branch
}

\author{
Mariana Angelia br Sinurat ${ }^{1}$, Endang Sulistya Rini ${ }^{2}$, \\ Rulianda Purnomo Wibowo ${ }^{2}$ \\ ${ }^{1,2}$ Master of Management Study Program on Postgraduate School of University of Sumatera Utara \\ Corresponding Author: Mariana Angelia br Sinurat
}

DOI: https://doi.org/10.52403/ijrr.20220226

\begin{abstract}
The Industry 4.0 era is an era of innovation and prioritizing technology and digitization in carrying out daily activities. This study aims to determine how much influence the omnichannel strategy has on customer loyalty through customer experience in the KCA (KREDIT CEPAT AMAN); Fast Secured Credit product of PT Pegadaian (Persero) Labuhan Deli SubBranch. This research is descriptive type research with a quantitative approach. The research sample consisted of 215 KCA customers of PT Pegadaian (Persero) Labuhan Deli Sub-Branch who had made KCA pawns using at least 2 channels. Based on the formulated hypothesis, the entire data analysis was processed using SEM - PLS analysis techniques using SmartPLS 3.0 software. Based on the results of the test, it was found that the exogenous variable (omnichannel strategy) had a positive and significant effect on the endogenous variable (customer loyalty) and the mediating variable (customer experience), the mediating variable (customer experience) had a positive and significant effect on the endogenous variable (customer loyalty). Based on the r-squared value, the exogenous variable (omnichannel strategy) was able to influence the mediating variable (customer experience) by $85.8 \%$ and the exogenous variable (omnichannel strategy) was able to influence the endogenous variable (customer loyalty) by $47.7 \%$.
\end{abstract}

Keywords: Omnichannel strategy, Customer Loyalty, Customer Experience

\section{BACKGROUND}

The Industry 4.0 era is an era that innovates by prioritizing AI (Artificial Intelligence), the internet in all fields, selfdriving vehicles, nanotechnology, renewable energy, quantum computing, and biotechnology. With this situation, new markets will emerge, new types of demand will arise. All business sectors must quickly make changes in providing the right facilities and needs for prospective customers, one of which is through digital marketing. Kotler et al. (2017) stated that the digital era or known as the Marketing 4.0 era is a marketing approach that combines online and offline interactions between companies and consumers.

Based on the current digitalization changes, the financial services industry sector must immediately make changes to obtain satisfaction that results in customer loyalty, especially for the current millennial generation who always involve technology in all aspects of life. To maintain and increase consumer loyalty to the company's services and products, the needs and desires of consumers must be a top priority.

Changes in the company's transformation in 2018 by PT Pegadaian 
(Persero) created a digital service pawn application and website (https://digital.pegadaian.co.id/), the pawnshop business line that will be investigated at PT Pegadaian (Persero) Labuhan Deli Sub-Branch is a financing business for KCA (KREDIT CEPAT $A M A N)$; Fast Secured Credit products. KCA is the product that is most in demand by customers, especially PT Pegadaian (Persero) Labuhan Deli Sub-Branch as many as 21,538 active customers per the year 2019. This is due to safe and fast processes and procedures so that customers who use KCA pawn products are most indemand compared to other pawnshop products.

KCA products can be accessed through the online pawn in the application. However, KCA products can only perform online booking services stages. So that KCA customers still have to come to the nearest branch to complete the pawn process. In addition, in 2019, pawnshops have added on-demand services with an omnichannel system for KCA products with the hope that customer experience in online transactions can increase revenue. In service realization, KCA products can only be used as collateral for jewellery and precious metals in the pickup and delivery service system. In addition, the limited time for pickup and delivery services has not been maximized in the implementation of omnichannel by pawnshops.

With the implementation that has not been maximized on the omnichannel strategy by the pawnshop, it has resulted in several complaints on the customer experience of PT Pegadaian (Persero) Labuhan Deli Sub-Branch's KCA products. Customers of PT Pegadaian (Persero) Labuhan Deli Sub-Branch feel that the online transaction experience is not optimal due to the frequent occurrence of application networks and websites that are under maintenance during their activities. In addition, the KCA online pawn process stops at the booking service stage so you have to go to the nearest pawnshop to complete the transaction to obtain loan funds. Meanwhile, a fully online system can only use collateral in the form of jewelry and precious metals.

Based on existing data for the last 4 years, the data obtained for the decrease in Outstanding Loans was caused by several things, namely customers who have completed borrowing funds, services that seem slow, causing long queues for transactions which result in complaints by customers. In addition, there are competitors for similar products, such as gold pawns with cheaper deposit fees, causing customers to switch companies. Pawnshops that focus on changes in the latest generation of technology can more or less have an impact on the OSL growth of $\mathrm{CP}$ Labuhan Deli Pegadaian, but it is not certain that the factor of change towards digitization will bring changes to the achievement of customer growth and OSL, especially in KCA products at Pegadaian CP Labuhan Deli in the future if possible maximally applied. This situation needs to be studied more deeply both internally and externally by the company.

From the description above, it can be seen that the omnichannel strategy that is being implemented by PT Pegadaian (Persero) Labuhan Deli Sub-Branch, can make the customer experience of KCA customers more enjoyable and whether the implementation of the omnichannel strategy can increase customer loyalty towards KCA products. How is the customer's assessment of KCA products that can be accessed online to offline, whether it is by the omnichannel Strategy? Based on these descriptions and phenomena, this research is entitled The Effect of Omnichannel Strategy on Customer Loyalty through Customer Experience on KCA Products (Fast Secured Credit) PT Pegadaian (Persero) Labuhan Deli Sub-Branch.

Emerson Wagner Mainardes, Carlos Anderson de Moura Rosa, and Silvania Neris Nossa (2020) conducted a study entitled "Omnichannel strategy and customer loyalty in banking" perceptions of 
service channel efficiency on loyalty attitudes in the banking sector and to examine the mediating effect of the effect of positive experience on this relationship. This research was conducted through a survey of 337 Brazilian bank clients with data analysis using structural equation modeling to assist banks in identifying relevant matters regarding their service channels. So they can determine how to generate a positive customer experience and customer loyalty through an omnichannel strategy. The results showed that the direct influence of the quality of the integrated interaction had a positive effect on bank customer loyalty. The direct effect of perceived service channel efficiency on loyalty is not significant. Other results also show that the positive effect of experience exerts a mediating effect on the proposed relationship between variables. The impact of the quality of integrated interactions and a seamless customer consumption experience is unprecedented in the banking industry, which demonstrates the importance of an omnichannel strategy in providing a positive banking customer experience. So it is necessary to understand that positive experience acts as a mediator between omnichannel strategy and bank customer loyalty.

Sara Quach, Mojtaba Barari, Dann Vit Moudrý, and Ken Quach (2020) conducted a study entitled "Service integration in omnichannel retailing and its impact on customer experience". The purpose of this study was to examine the effect of two components of service integration in omnichannel retailing, (i.e. service consistency and service transparency), consumer experience (i.e. flow and perceived privacy risk), and consumer loyalty. The selected population is Walmart consumers who have had omnichannel experience for the last 6 months with a total number of 786 respondents. The results show that service consistency has a direct and significant impact on flow and perceived risk while only the effect of service flow transparency is significant. In addition, perceived flow and risk are related to consumer loyalty to retailers. Furthermore, it was found that showrooming behavior and the use of location-based services moderated the relationship between service consistency and privacy risk. The research findings provide important implications for retailers regarding the development, implementation, and management of omnichannel strategies.

\section{Omnichannel strategy}

Omnichannel strategy is an approach concept based on the customer's point of view by providing an integrated shopping experience to increase customer satisfaction through the design of an effective shopping model. The implementation of an omnichannel strategy enables business owners to achieve higher profits, through increased sales and more efficient operations.

The indicators used as a reference in this study use the UTAUT2 model through seven factors: performance expectancy, effort expectancy, social influence, facilitating conditions, hedonic motivations, price value, and habits. As well as adding two supporting factors, namely personal innovativeness and perceived security so that the measurement of the omnichannel dimension is performance expectancy, effort expectancy, social influence, habits, hedonic motivations, personal innovativeness and perceived security.

\section{Customer Loyalty}

Customer loyalty is a customer's commitment to a brand, store, or supplier based on a very positive nature and is reflected in consistent repeat purchases. The indicators used as a reference in the research based on research by Griffin (2005) Make regular repeat purchases, purchases across product and service lines, refer others (recommend to others), and demonstrate immunity to the pull of the competition. 


\section{Customer experience}

The experience a customer feels is a result of the interaction between that customer and a company over the length of their relationship. These interactions include customer interest, awareness, discovery, development, advocacy, and purchasing, as well as product/service use. The indicators used as a reference in the research based on research by Lemke et al (2006) with eight factors that influence Business to Customer (B2C) customer experience, namely accessibility, competence, customer recognition, helpfulness, personalization, problem-solving, promise fulfillment, value for time.

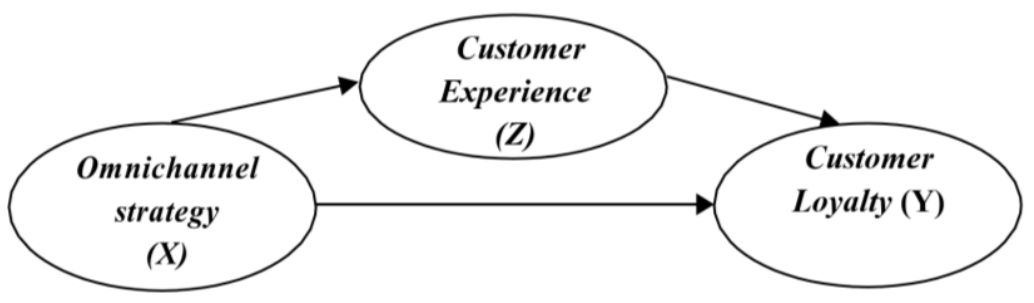

Figure 1. Conceptual Framework

\section{Hypotheses}

H1: Omnichannel strategy has a positive effect on customer loyalty.

H2: Omnichannel strategy has a positive effect on customer experience.

H3: Customer experience has a positive effect on customer loyalty.

H4: Omnichannel strategy affects customer loyalty through customer experience

\section{RESEARCH METHOD}

This type of research is descriptive research with a quantitative approach that explains the relationship between the variables studied. The population in this study is addressed to customers of PT Pegadaian (Persero) Labuhan Deli SubBranch who have borrowed funds with a pawn system on Fast Secured Credit (KCA) products using at least two channels, offline and online. In connection with a large population, the sample of this study uses non-probability sampling with purposive sampling method, which means that the population used as the research sample is a population that meets certain sample criteria according to the research objectives. The number of samples is 215 people. To determine the level of validity and reliability of the questionnaire which was processed using the SmartPLS 3.0 program.

\section{RESULT AND DISCUSS \\ Structural (Inner) Model Testing}

Table 1. $R$-squared and $Q$-squared Value
\begin{tabular}{|l|c|c|}
\hline & Customer experience $(\mathrm{Z})$ & Customer Loyalty $(\mathbf{Y})$ \\
\hline $\boldsymbol{R}$-squared & 0,858 & 0,477 \\
\hline$Q$-squared & 0,667 & 0,406 \\
\hline
\end{tabular}

The results from the inner model show that the r-squared value on the customer experience mediation variable is 0.858 , which means that the influence of the exogenous omnichannel strategy variable on the customer experience mediation variable is $85.8 \%$ and the r-squared on the endogenous variable, namely customer loyalty, is 0.477 , which means that the effect of exogenous variables, namely omnichannel strategy on endogenous variables, namely customer loyalty is only $47.7 \%$. Meanwhile, the q-squared value on the mediating variable, namely customer experience, is 0.667 and the endogenous variable, namely customer loyalty, is 0.406 . It is concluded that the value of predictive validity is greater than 0 , then the research data that has been distributed already has a well-constructed and predictive relationship. 
Mariana Angelia br Sinurat et.al. The effect of omnichannel strategy on customer loyalty through customer experience in kca (kredit cepat aman) product at pt pegadaian (persero) labuhan deli sub-branch.

\section{Hypothesis Testing}

Table 2. Research Hypothesis Test Results

\begin{tabular}{|l|c|c|c|c|}
\hline \multicolumn{1}{|c|}{ Hypotheses } & $\begin{array}{c}\text { Original } \\
\text { Sample } \\
(\boldsymbol{O})\end{array}$ & $\begin{array}{c}\text { Sample } \\
\text { Mean } \\
(\boldsymbol{M})\end{array}$ & $\begin{array}{c}\text { Standard } \\
\text { Deviation } \\
(\text { STDEV })\end{array}$ & $\begin{array}{c}\text { T Statistics } \\
(\boldsymbol{O} / \text { STDEV })\end{array}$ \\
\hline $\begin{array}{l}\text { Omnichannel strategy (X) -> Customer } \\
\text { Loyalty (Y) }\end{array}$ & 0.421 & 0.415 & 0.089 & 4.713 \\
\hline $\begin{array}{l}\text { Omnichannel strategy (X) -> Customer } \\
\text { experience (Z) }\end{array}$ & 0.927 & 0.926 & 0.013 & 68.947 \\
\hline $\begin{array}{l}\text { Customer experience (Z) -> Customer } \\
\text { Loyalty (Y) }\end{array}$ & 0.286 & 0.287 & 0.068 & 4.186 \\
\hline $\begin{array}{l}\text { Omnichannel strategy (X) -> Customer } \\
\text { experience (Z) -> Customer Loyalty (Y) }\end{array}$ & 0.265 & 0.266 & 0.065 & 4.079 \\
\hline
\end{tabular}

The first hypothesis tests whether the omnichannel strategy has a positive effect on customer loyalty. The test results show the coefficient of beta omnichannel strategy on customer loyalty is 0.421 and the t-statistic is 4.713 . From these results, it is stated that the t-statistic is significant because it is greater than 1.96 with p-values 0.000 which is smaller than 0.05 so the first hypothesis is accepted. This proves that the omnichannel strategy is proven to have a positive influence on customer loyalty.

The results of the omnichannel strategy research at PT Pegadaian (Persero) Labuhan Deli Sub-Branch, it is known that the dimensions of social influence and perceived security are dimensions that need to be improved again so that people especially in the Labuhan Deli area understand the omnichannel system that has been implemented by PT Pegadaian (Persero) Labuhan Deli Sub-Branch. The digital service pawnshop needs to be reevaluated the system and network so that it can be easily accessed by users and provide education to the people of Labuhan Deli so that people are more interested in operating digital pawnshop services in transacting KCA products online and other products owned by the pawnshop. In the dimensions of performance expectancy, habit, and personal innovativeness, it is quite good to influence customer loyalty which states that the integration channel carried out by the pawnshop fulfills the wishes of customers personally, especially in an era of high mobility so that the internet and cellular phones make it easier for customers to make pawns anywhere and anytime.

The second hypothesis tests whether the omnichannel strategy has a positive effect on customer experience. The test results show that the coefficient of beta omnichannel strategy on customer experience is 0.927 and the t-statistic is 68.947. From these results, it is stated that the t-statistic is significant because it is greater than 1.96 with p-values 0.000 less than 0.05 so that the second hypothesis is accepted. This proves that the omnichannel strategy is proven to have a positive influence on customer experience.

In this study, the currently available online system still does not simplify the process of pawning KCA and making timeefficient in the process of pawning KCA. This is because the existing online KCA system still has to be completed by visiting the nearest pawnshop branch to process transactions and sign files. So that the experience felt by the customer is still not fully maximized and if you want to improve that experience, the pawnshop must carry out a fully online system related to the KCA pawn product at PT Pegadaian (Persero) Labuhan Deli Sub-Branch. So that it can improve promise fulfillment and problemsolve on pawnshop customer experience indicators.

The third hypothesis examines whether customer experience positively affects customer loyalty. The test results show that the beta coefficient of customer experience on customer loyalty is 0.286 and the t-statistic is 4.816 . From these results, it 
is stated that the t-statistic is significant because it is greater than 1.96 with $\mathrm{p}$-values 0.000 less than 0.05 so the third hypothesis is accepted. This proves that customer experience is proven to have a positive influence on customer loyalty.

The current customer experience has a positive effect on customer loyalty of PT Pegadaian (Persero) Labuhan Deli SubBranch, so based on the results of research on the customer experience variable, the main thing that becomes a reference for customers in experiencing a positive experience is through the dimensions of competence, helpfulness and maximum personalization given by PT Pegadaian (Persero) Labuhan Deli Sub-Branch to KCA customers. Customer experience is a psychological feeling that is in the minds of consumers so consumer experience has a positive effect on attitude loyalty and behavioral loyalty.

The fourth hypothesis tests that customer experience has a mediating effect on the relationship between omnichannel strategy and customer loyalty. The test results show that the beta coefficient value of the mediation effect of customer experience on the relationship between omnichannel strategy and customer loyalty is 0.265 and the t-statistic is 4.079. From these results, it is stated that the t-statistic is significant because it is greater than 1.96 with p-values 0.000 less than 0.05 so the fourth hypothesis is accepted. This proves that customer experience is proven to be able to mediate the relationship between omnichannel strategy and customer loyalty.

This proves that to gain customer loyalty such as making repeated transactions, making purchases in all product lines of pawnshops, recommending to others, and not being interested in similar products from competitors to be sustainable, an omnichannel strategy is needed that integrates all offline and online services to provide a seamless customer experience which causes a positive experience felt by customers of PT Pegadaian (Persero) Labuhan Deli Sub-Branch. Especially during the COVID-19 pandemic, which has not yet been completed, pawnshops must be able to convince customers that pawnshop products can be processed online with a digital service pawnshop system so that they can be done anytime and anywhere without having to go to the nearest pawn shop. So that transactions can continue to run safely from the coronavirus by providing more service to its customers online and quickly.

\section{CONCLUSION}

1. The omnichannel strategy variable has a positive and significant effect on customer loyalty. This shows that the omnichannel strategy carried out by PT Pegadaian (Persero) Labuhan Deli SubBranch is still not optimal, so it is necessary to implement several strategies and policies to increase customer loyalty, especially during the COVID-19 pandemic, which continues to this day.

2. The omnichannel strategy variable has a positive and significant effect on customer experience. This shows that the omnichannel strategy carried out by PT Pegadaian (Persero) Labuhan Deli Sub-Branch is still not optimal to improve the customer experience of PT Pegadaian (Persero) Labuhan Deli SubBranch customers. So that the omnichannel strategy needs to be reviewed and improved again to improve the customer experience of PT Pegadaian (Persero) Labuhan Deli SubBranch customers.

3. The customer experience variable has a positive and significant effect on customer loyalty. This shows that the customer's customer experience

4. PT Pegadaian (Persero) Labuhan Deli Sub-Branch needs to be improved again to increase customer loyalty, especially in the conditions of the COVID-19 pandemic which is continuing today.

5. The influence of omnichannel strategy on customer loyalty through customer experience as a mediating variable has a significant influence. From the SEM- 
PLS analysis, it was found that the omnichannel strategy has a direct influence on customer experience and customer loyalty, as well as customer experience on customer loyalty. Although the influence of each variable is greater than the indirect variable. The customer experience variable is still able to mediate between the omnichannel strategy and customer loyalty.

\section{Acknowledgement: None}

\section{Conflict of Interest: None}

\section{Source of Funding: None}

\section{REFERENCES}

1. Afiana, F. N, P. Subarkah, dan A.K. Hidayat. (2019). Analisis Perbandingan Metode Tam Dan Metode Utaut 2 Dalam Mengukur Kesuksesan Penerapan Simrs Pada Rumah Sakit Wijaya Kusuma Dkt Purwokerto. Jurnal MATRIK. 19(1), 17-26 DOI https://doi.org/10.30812/matrik.v19i1.432

2. Ayensa, E.J., A. Mosquera, dan Y. Murillo. (2016). Omnichannel Customer Behavior: Key Drivers of Technology Acceptance and Use and Their Effects on Purchase Intention. Frontiers in Psychology. 7(1117). DOI: 10.3389/fpsyg.2016.01117

3. Ghozali, I. (2008). Structural Equation Modelling, Edisi II, Universitas Diponegoro, Semarang.

4. Ghozali, I. Latan, H. (2012). Partial Least Square : Konsep, Teknik dan Aplikasi SmartPLS 2.0 M3. Semarang: Badan Penerbit Universitas Diponegoro

5. Griffin, J. (2005). Customer Loyalty: Menumbuhkan dan Mempertahankan Kesetiaan Nasabah. Jakarta: Erlangga.

6. Hair, J., W. Black, B.J. Babin, dan R. Anderson. (2010). Multivariate Data Analysis (7th ed). United States: Pearson.

7. Ieva, M dan C. Ziliani. (2017). The role of customer experience touchpoints in driving loyalty intentions in services. TQM Journal, 30 (5). 444-457. https://doi.org/10.1108/TQM-11-2017-0141

8. Kamath, P.R., Y.P. Pai dan N.K.P. Prabhu. (2019). Building customer loyalty in retail banking: a serial-mediation approach.
International Journal of Bank Marketing, $38(2)$, 456-484. https://doi.org/10.1108/IJBM-01-2019-0034

9. Kazancoglu, Ipek dan H. Aydin. (2018). An investigation of consumers' purchase intentions towards omnichannel shopping: A qualitative exploratory study. International Journal of Retail \& Distribution Management, 46(10), 959976. https://doi.org/10.1108/IJRDM-042018-0074

10. Kotler, P., H. Kertajaya., dan I. Setiawan. 2017. Marketing 4.0: Moving from Traditional to Digital. Jakarta: PT. Gramedia Pustaka Utama.

11. Lemke, F., M. Clark, dan H. Wilson. (2006). What Makes a Great Customer Experience. The Henley Centre for Customer Management, Henley University of Reading.

12. Mainardes, E.W., C.A.d.M. Rosa, dan S.N. Nossa. (2020). Omnichannel strategy and customer loyalty in banking. International Journal of Bank Marketing, 38(4). 799-822. https://doi.org/10.1108/IJBM-07-2019-0272

13. Makudza, Forbes. (2020). Augmenting customer loyalty through customer experience management in the banking industry. Journal of Asian Business and Economic Studies. 27(2). 1-13. DOI: 10.1108/JABES-01-2020-0007

14. Malhotra, N.K. (2004). Marketing Research: An Applied Orientation. 4th Edition. New Jersey: Pearson Education Inc.

15. Meyer, C., dan A. Schwager. (2007). Understanding Customer Experience. Harvard Business Review, 85(2). 116-157. Diakses dari https://mycourses.aalto.fi/

16. Mirsch, T, C. Lehrer, dan R. Jung. (2016). Channel Integration Towards Omnichannel Management: A Literature Review. Pacific Asia Conference on Information Systems (PACIS). Chiayi, Taiwan. Corpus ID: 9827770

17. Moreno, F.M., J.G. Lafuente, F.A. Carreón dan S.M. Moreno (2017). The Characterization of the Millennials and Their Buying Behavior. International Journal of Marketing Studies. 9(5), 135-144. DOI:10.5539/items.v9n5p135

18. Mosquera, A., C.O. Pascual, dan E.J. Ayensa. (2017). Understanding the Customer Experience in the Age of OmniChannel Shopping. Icono14. 15(2). 166188. DOI: ri14.v15i2.1070. 
Mariana Angelia br Sinurat et.al. The effect of omnichannel strategy on customer loyalty through customer experience in kca (kredit cepat aman) product at pt pegadaian (persero) labuhan deli sub-branch.

19. Nobar, H. B, dan R. Rostamzadeh. 2018. The Impact of Customer Satisfaction, Customer Experience and Customer Loyalty on Brand Power: Empirical Evidence from Hotel Industry. Journal of Business Economics and Management. 19(2). 417430. DOI: $10.3846 /$ jbem.2018.5678

20. Payne, A., dan P. Frow. (2005). A strategic framework for customer relationship management. Journal of Marketing, 69(4), 167-176. DOI: $10.2307 / 30166559$

21. Quach, Sara, M. Barari, D. V. Moudrý dan Ken Quach. (2020). Service integration in omnichannel retailing and its impact on customer experience. Journal of Retailing and Consumer Services. https://doi.org/10.1016/j.jretconser.2020.10 2267

22. Santoso, S. (2014). Statistik Parametrik Edisi Revisi. Jakarta: Elex Media Komputindo

23. Simone, A. dan E. Sabbadin. (2018). The New Paradigm of the Omnichannel Retailing: Key Drivers, New Challenges and Potential Outcomes Resulting from the Adoption of an Omnichannel Approach. International Journal of Business and Management, 13(1). 85-109. DOI:10.5539/ijbm.v13n1p85.

24. Srivastava, Mala dan D. Kaul (2016). Exploring the link between customer experience-loyalty-consumer spending. Journal of Retailing and Consumer Services. 31. 277-286. http://dx.doi.org/10.1016/j.jretconser.2016.0 4.009

25. Sugiyono. (2013). Metode Penelitian Bisnis (Pendekatan Kuantitatif, Kualitatif, dan R\&D). Bandung: Alfabeta.
26. Tyrvainen, Olli, H. Karjaluoto, $\mathrm{H}$. Saarijarvi. (2020). Personalization and hedonic motivation in creating customer experiences and loyalty in omnichannel retail. Journal of Retailing and Consumer Services. $25.21-10$. https://doi.org/10.1016/j.jretconser.2020.10 2233.

27. Yuswohady et. al. (2020). E-book Marketing Outlook 2020. https://inventure.id/wpcontent/uploads/2019/12/EBOOKMARKETING-OUTLOOK-2020FINAL.pdf (diakses tanggal 28 agustus 2020)

28. Zeithaml, V.A. dan M.J. Bitner. (1996). Service Marketing Integrating Customer Focus Across the Firm. International edition. North America: McGraw-Hill Companies, Ltd.

29. Liliyah, A. (2020). IG Live - SWA Business Leader Talk: Strategi Inovasi dan Transformasi Digital Pegadaian. https://swa.co.id/swa/ceo-interview/ig-liveswa-business-leader-talk-strategi-inovasidan-transformasi-digital-pegadaian

How to cite this article: Mariana Angelia br Sinurat, Endang Sulistya Rini, Rulianda Purnomo Wibowo. The effect of omnichannel strategy on customer loyalty through customer experience in $\mathrm{kca}$ (kredit cepat aman) product at pt pegadaian (persero) labuhan deli sub-branch. International Journal of Research and Review. 2022; 9(2): 181-188. DOI: https://doi.org/10. 52403/ijrr.20220226 